\title{
In vitro Regeneration by Somatic Embryos of Maize Inbreds Using Mature Seeds
}

\author{
N.K. Dhillon ${ }^{1 *}$ and S.S. Gosal ${ }^{2}$ \\ ${ }^{1}$ Department of Plant Breeding and Genetics, Punjab Agricultural University, \\ Ludhiana-141004, Punjab, India \\ ${ }^{2}$ Punjab Agricultural University, Ludhiana-141004, Punjab, India \\ *Corresponding author
}

\section{A B S T R A C T}

\section{Keywords}

Maize, Mature seed, Somatic embryogenesis, SEM

Article Info

Accepted:

07 October 2018

Available Online:

10 November 2018
Five maize lines prevalently used by breeders in the maize program were screened for their ability to form type II callus. Mature seeds were used as explant for in vitro culturing. One inbred line showed high embryogenic response and formed friable, type II calli and also exhibited successful plant regeneration. Ten culture media compositions based on Murashige and Skoog (1962) salts thus investigated differed with respect to the combinations of concentrations of auxins (IBA, NAA, picloram, 2, 4-D) and cytokinins (BAP, kinetin) were used. Highest percent callus induction and subsequent somatic embryogenesis were observed in inbred LM13. The embryogenic calli were maintained and multiplied on regeneration medium containing reduced levels of auxins. Medium MS + Proline $\left(3.0 \mathrm{gL}^{-1}\right)+$ BAP $\left(3.0 \mathrm{mgL}^{-1}\right)+\mathrm{Kn}\left(0.5 \mathrm{mgL}^{-1}\right)+$ Gelrite $(0.2 \%)$ unsurpassed plant regeneration capacity. This efficient regeneration system provides a solid basis for genetic transformation of maize.

\section{Introduction}

Maize is classified in tropical and temperate varieties that nurture at different latitudes and under different climatic conditions. Tropical maize is indigenous to tropical regions, including Latin America and sub-Saharan Africa (Anami et al., 2009). Economically, maize is an important crop, presenting a multibillion dollar annual revenue (Schnable et al., 2009). By the year 2020, maize will surpass both rice and wheat in global demand (Pingali and Pandey, 2001). At the International Maize and Wheat Improvement Center (CIMMYT), Large collections of maize germplasm exist, which comprises inbreds, hybrids, synthetic cultivars, openpollinating varieties, and improved landraces, and represent resources for genetic diversity to be used in breeding programmes and agriculture. Besides its agronomic importance, maize is a model organism for basic and applied research (Strable and Scanlon, 2009). Its genome is diploid, with a size of 2.3 gigabase, and consist of more than 32,000 genes as determined in the temperate B73 line (Schnable et al., 2009). The success of tropical maize improvement is limited because of low genetic variations in the gene pools as a result of domestication, high costs and long 
generation times to produce a single improved selection (Xu et al., 2009). Relying on conventional breeding and clonal selections of elite maize types and multiplying to be distributed to growers, especially in developing countries is not sufficient. Future demands require new and upgradation of highyield cultivars. A biotechnological approach combining tissue culture and genetic transformation with genes of interest can produce genetically transformed germplasm (Anami et al., 2010). Although immature embryo cultures have been used in tropical maize genotypes for regeneration (Prioli and da Silva 1989; Bohorova et al., 1995; Carvalho et al., 1997; Oduor et al., 2006) but very little work has been done on Indian mature embryos. In the past, plant regeneration has been achieved from callus cultures from mature embryos in cereals (Green and Phillips, 1974; Wang, 1987, Rueb et al., 1994; Ozgen et al., 1998; zgen et al., 1998; Akula et al., 1999; Ward and Jordan 2001). Green et al., (1974) first reported that mature embryo of maize could be used to induce callus but no plantlets were regenerated. Successfully regenerated plants from mature embryos of two maize inbreds B73 and Mo17, but the regeneration was genotype- dependent and the frequency was only 4-5\% Wang (1987).

Huang and Wei (2004) reported regeneration of temperate maize lines from mature embryos at a frequency ranging from 19.85 to $32.4 \%$. The use of mature embryos from dry seeds has a number of advantages: mature embryos are easy to handle, available year round and in bulk quantities.

We present here regeneration system based upon initiation of embryogenic calli from mature embryos of maize. Our results provide a helpful basis for expanding the success for regeneration and transformation of Indian maize inbred lines.

\section{Materials and Methods}

The mature grains of maize inbred line being used as parent for developing commercial maize hybrids locally were obtained from Maize Section, Department of Plant Breeding and Genetics, Punjab Agricultural University Ludhiana. The seeds were surface sterilized by using mercuric chloride $(0.1 \%)$ for 10 minutes followed by three washings with sterile distilled water.

Sterilized seeds were then cultured on MS (Murashige and Skoog, 1962) medium for primary callus induction supplemented with casein hydrolysate $(500 \mathrm{mg} / \mathrm{l})$, proline $(500$ $\mathrm{mg} / \mathrm{l})$, silver nitrate $(10 \mathrm{mg} / \mathrm{l})$, sucrose $(60 \mathrm{~g} / \mathrm{l})$, 2,4-D (3.0 mg/l), (6.0 mg/l), (10.0 mg/l), Picloram $(2.5 \mathrm{mg} / \mathrm{l}),(5.0 \mathrm{mg} / \mathrm{l}),(10.0 \mathrm{mg} / \mathrm{l})$ along with NAA $(0.75 \mathrm{mg} / \mathrm{l})$ and BAP $(0.5$ $\mathrm{mg} / \mathrm{l})$ in test tubes. All these callus induction media were solidified with agar $(8.0 \mathrm{~g} / \mathrm{l})$. Different media combinations were evaluated. $\mathrm{MS}+\operatorname{Pic}\left(10.0 \mathrm{mgL}^{-1}\right)+\operatorname{BAP}\left(0.5 \mathrm{mgL}^{-1}\right)$ was the best media for callus induction.

For Callus initiation, the cultures were incubated in total dark in a growth room maintained at $25 \pm 2^{\circ} \mathrm{C}$. Excised embryos were cultured without light at $25 \pm 1^{\circ} \mathrm{C}$. After 3 to 7 $\mathrm{d}$, development of callus and germination was observed from whole embryos. To promote proliferation of callus, elongated shoots and roots from mature embryos were detached, and callus responding explants inoculated again in the same Petri dish. After 2 to 3 weeks, scutellar tissues which did not generate callus were separated and discarded from intact callus. After 5 weeks from initial plating, amount of callus was scored.

For embryogenic calli formation, the concentrations of 2,4-D and picloram were reduced to half in each of the callus maintenance media and solidified with $8.0 \mathrm{~g} / \mathrm{l}$ agar for the induction of somatic 
embryogenesis. MS + NAA $\left(5 \mathrm{mgL}^{-1}\right)+$ Kinetin $\left(0.5 \mathrm{mgL}^{-1}\right)$ was the optimum medium for somatic embryo induction. Each experiment was repeated three times in Completely Randomized Block Design with hundred explants per replication. Statistical analysis was done using CPCS-1 software package developed at Punjab Agricultural University (Cheema and Singh, 1990).

For plant regeneration, after 4 to 5 weeks of embryogenic callus induction, all embryogenic calli were transferred to regeneration media (Table 1) for regeneration and cultured for 3 weeks under low light.

At the end of 3 weeks, most embryogenic calli developed into shoots/plantlets. All regenerated green plantlets were counted from each callus line, and callus that did not regenerate completely was subcultured once more on the same medium for an additional 2 to 3 weeks. Consequently, numbers of shoots and plantlets were counted again and summed with first counts to estimate total regeneration.

For roots formation, regenerated shoots over 3 $\mathrm{cm}$ high were positioned onto rooting medium for estimation of root development. Rooting medium was half-strength MS medium was solidified with $5 \mathrm{~g} / \mathrm{L}$ agar. The $\mathrm{pH}$ of the medium was adjusted to 5.8 before autoclaving.

Cultures for rooting were kept at $25 \pm 1{ }^{\circ} \mathrm{C}$ with a 16/8 hr (light/dark) photoperiod for 2 to 3 weeks. To observe normal growth and fertility, well-rooted plants, with a similar number of seed-initiated plants were removed from medium, rinsed in water to remove media, and transplanted into a mixture of equal parts $(\mathrm{v} / \mathrm{v})$ of sterilized soil and vermiculite, and grown under humid conditions in a growth room at $25 \pm 1^{\circ} \mathrm{C}$ for 2 weeks. Subsequently, plants were moved into a greenhouse and grown to maturity.

\section{Results and Discussion}

The most commonly and widely used explants for callus induction in maize has been studied to be immature embryos (Frame et al., 2002). In addition to the difficulty of maintaining a continuous supply of immature embryos round the year, mature embryos have been used to induce callus and regenerate plants (Green $e t$ al., 1974; Wang, 1987; Huang and Wei, 2004).Whereas, mature embryos have been found to be less responsive to tissue culture manipulations (Wang, 1987; Huang and Wei, 2004). The mature seed explant was used with a thought of keeping the seed contents intact at the time of culturing, in view of the fact that natural nutrients and growth hormones are stored within the endosperm. Besides, maize seed can be handled as a dicotyledonous seed.

Our studies revealed that media composition, i.e., $\mathrm{MS}+\mathrm{Pic}\left(10.0 \mathrm{mgL}^{-1}\right)+\mathrm{BAP}\left(0.5 \mathrm{mgL}^{-1}\right)$ was best for callus induction for all inbreds. The use of picloram resulted in higher frequency of callus induction. This may be due to the fact that picloram is a strong auxin as compared to other or there may be synergistic effect that promoted callusing. Picloram has been used to induce callusing even in recalcitrant genotypes (Eisinger and Morré, 1971). Earlier Bhaskaran and Smith (1990) have also shown that the use of cytokinins in combination with auxins induces somatic embryogenesis from callus cultures in cereals. It is thus apparent that maize is difficult system and it requires the use of strong auxin to initiate callusing especially from the mature seeds (Fig. 1). Picloram has also been used to induce callus from mature seeds earlier (Huang and Wei, 2004; Abebe et al., 2008). Tissue culture of mature maize seeds typically produced two different types of calli designated as type I and type II. Type I callus was dirty white, slow growing and compact callus while type II was soft, friable, fast growing and embryogenic. 
Table.1 Per cent regeneration from mature embryos derived embryogenic calli of five maize inbreds cultured on different media compositions

\begin{tabular}{|c|c|c|c|c|c|}
\hline \multirow{3}{*}{$\begin{array}{c}\text { MS media + } \\
\text { Growth } \\
\text { hormones } \\
(\mathrm{mg} / \mathrm{l})\end{array}$} & \multicolumn{5}{|c|}{ Callus regeneration (\%) } \\
\hline & \multicolumn{5}{|c|}{ Mature Grain } \\
\hline & LM 5 & LM 6 & LM 13 & LM 15 & LM 16 \\
\hline MS & $\begin{array}{c}7.6 \pm 2.0 \\
(15.8)\end{array}$ & $\begin{array}{c}10.6 \pm 1.2 \\
(19.0)\end{array}$ & $\begin{array}{c}7.6 \pm 2.1 \\
(15.8)\end{array}$ & $\begin{array}{c}5.3 \pm 1.7 \\
(12.9)\end{array}$ & $\begin{array}{c}4.6 \pm 1.2 \\
(12.3)\end{array}$ \\
\hline $2,4-D(0.25)$ & $\begin{array}{c}1.3 \pm 0.8 \\
(5.2)\end{array}$ & $\begin{array}{c}5.6 \pm 1.4 \\
(13.5)\end{array}$ & $\begin{array}{c}2.6 \pm 0.3 \\
(9.4)\end{array}$ & $\begin{array}{c}1.6 \pm 0.8 \\
(6.0)\end{array}$ & $\begin{array}{c}4.3 \pm 1.4 \\
(11.7)\end{array}$ \\
\hline $\begin{array}{c}2,4-D(0.25)+ \\
\text { NAA }(1.0)\end{array}$ & $\begin{array}{c}0.3 \pm 0.3 \\
(1.9)\end{array}$ & $\begin{array}{c}1.0 \pm 0.5 \\
(4.6)\end{array}$ & $\begin{array}{c}0.6 \pm 0.6 \\
(2.7)\end{array}$ & $\begin{array}{c}0.3 \pm 0.3 \\
(1.9)\end{array}$ & $\begin{array}{c}0.6 \pm 0.3 \\
(3.8)\end{array}$ \\
\hline NAA (1.0) & $\begin{array}{c}3.3 \pm 0.8 \\
(10.3)\end{array}$ & $\begin{array}{c}1.3 \pm 0.6 \\
(5.4)\end{array}$ & $\begin{array}{c}5.3 \pm 1.4 \\
(13.1)\end{array}$ & $\begin{array}{c}4.6 \pm 1.4 \\
(12.1)\end{array}$ & $\begin{array}{c}3.3 \pm 0.8 \\
(10.3)\end{array}$ \\
\hline $\begin{array}{c}\text { BAP }(4.0)+ \\
\text { Kn }(0.5)+ \\
\text { Gelrite } \\
(0.2 \%)\end{array}$ & $\begin{array}{c}17.0 \pm 2.0 \\
(24.3)\end{array}$ & $\begin{array}{c}17.3 \pm 3.1 \\
(24.4)\end{array}$ & $\begin{array}{c}19.6 \pm 3.1 \\
(26.2)\end{array}$ & $\begin{array}{c}12.3 \pm 2.3 \\
(20.4)\end{array}$ & $\begin{array}{c}11.3 \pm 1.2 \\
(19.6)\end{array}$ \\
\hline $\begin{array}{c}\text { BAP }(3.0)+ \\
\text { Kn }(0.5)+ \\
\text { Gelrite } \\
(0.2 \%)\end{array}$ & $\begin{array}{c}12.3 \pm 1.7 \\
(20.5)\end{array}$ & $\begin{array}{c}10.6 \pm 2.7 \\
(18.8)\end{array}$ & $\begin{array}{c}11.6 \pm 1.4 \\
(19.9)\end{array}$ & $\begin{array}{c}3.6 \pm 1.2 \\
(10.8)\end{array}$ & $\begin{array}{c}6.3 \pm 1.8 \\
(14.3)\end{array}$ \\
\hline $\begin{array}{c}\text { BAP }(2.0)+ \\
\text { Kn }(0.5)+ \\
\text { Gelrite } \\
(0.2 \%)\end{array}$ & $\begin{array}{c}12.6 \pm 1.3 \\
(20.8)\end{array}$ & $\begin{array}{c}9.6 \pm 2.3 \\
(17.9)\end{array}$ & $\begin{array}{c}11.3 \pm 1.7 \\
(19.5)\end{array}$ & $\begin{array}{c}6.6 \pm 1.7 \\
(14.7)\end{array}$ & $\begin{array}{c}5.0 \pm 1.5 \\
(12.6)\end{array}$ \\
\hline $\begin{array}{c}\text { Proline }(3.0 \mathrm{~g}) \\
+ \text { BAP }(3.0)+ \\
\text { Kn }(0.5)+ \\
\text { Gelrite } \\
(0.2 \%)\end{array}$ & $\begin{array}{c}20.3 \pm 2.9 \\
(26.7)\end{array}$ & $\begin{array}{c}26.6 \pm 2.0 \\
(32.1)\end{array}$ & $\begin{array}{c}28.3 \pm 2.9 \\
(31.0)\end{array}$ & $\begin{array}{c}17.3 \pm 1.7 \\
(24.5)\end{array}$ & $\begin{array}{c}16.6 \pm 2.6 \\
(24.0)\end{array}$ \\
\hline IBA (1.0) & $\begin{array}{c}10.3 \pm 2.0 \\
(18.6)\end{array}$ & $\begin{array}{c}9.3 \pm 2.4 \\
(17.5)\end{array}$ & $\begin{array}{c}14.3 \pm 2.4 \\
(22.1)\end{array}$ & $\begin{array}{c}3.6 \pm 1.2 \\
(10.8)\end{array}$ & $\begin{array}{c}3.3 \pm 0.8 \\
(10.3)\end{array}$ \\
\hline IBA $(2.0)$ & $\begin{array}{c}11.3 \pm 2.4 \\
(19.5)\end{array}$ & $\begin{array}{c}11.6 \pm 1.7 \\
(19.9)\end{array}$ & $\begin{array}{c}14.6 \pm 1.4 \\
(22.5)\end{array}$ & $\begin{array}{c}6.0 \pm 1.5 \\
(14.0)\end{array}$ & $\begin{array}{c}4.3 \pm 0.8 \\
(11.9)\end{array}$ \\
\hline
\end{tabular}

$*$ Values represent means \pm SD of three replications with twenty explants per replication **Values in the parentheses are arc sine transformed values 
Fig.1 Callus induction, somatic embryogenesis, and plant regeneration from isolated mature embryos of maize inbreds

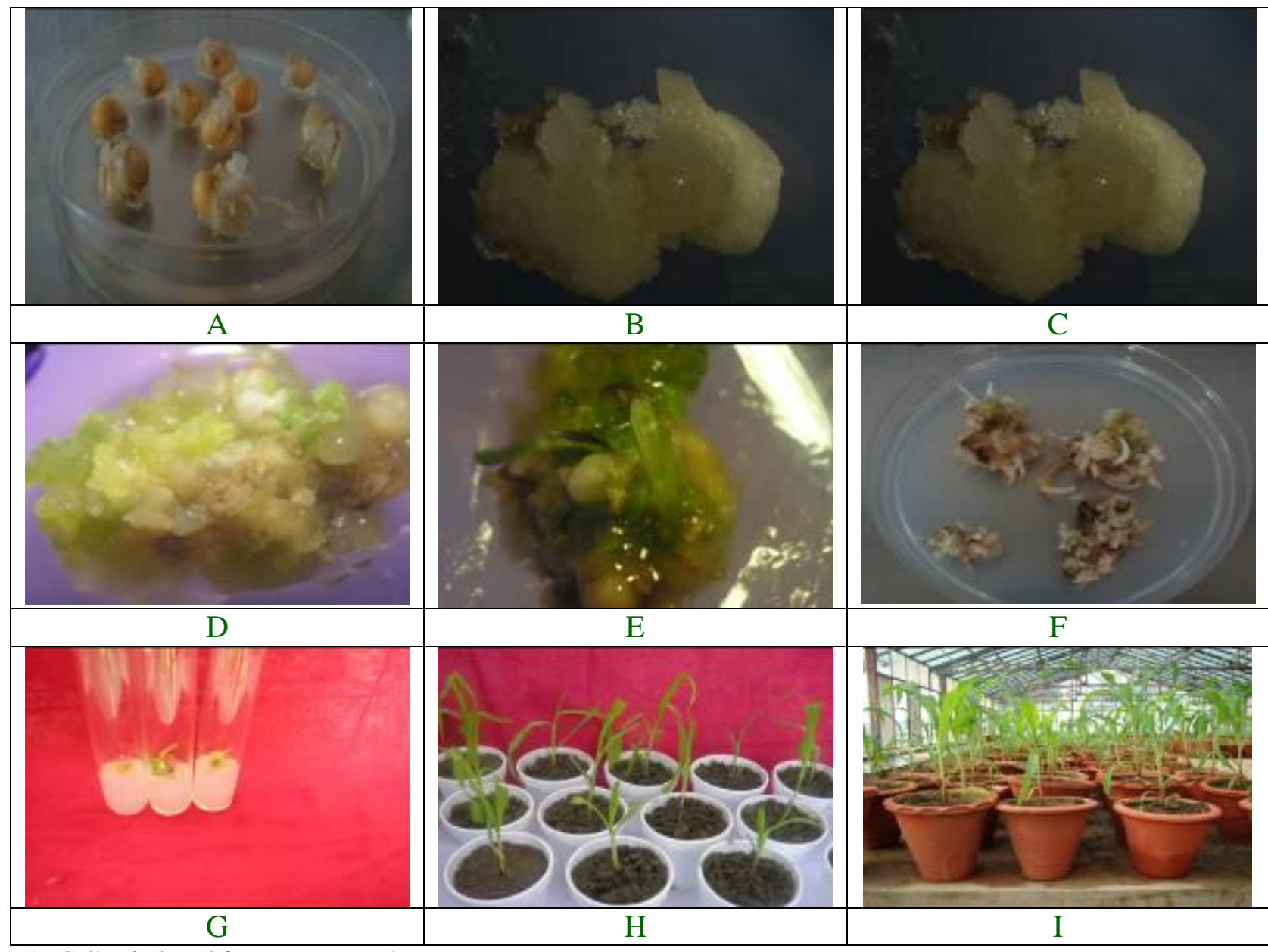

A: Callus induced from mature embryos

B: Formation of whitish friable non-embryogenic callus (soft and watery)

C: Explant showing the development of multiple somatic embryos

D: Chlorophyll development in regenerating callus

E: Regeneration of somatic embryo

F: Compact germinating somatic embryo with developing shoots

G: Regenerating somatic embryos into small shoots and plantlets

$\mathrm{H}$ : Hardening of regenerated plants

I: Plantlet regenerated from mature embryo growing in greenhouse

Similar observations have been made by (Armstrong and Green 1985; Armstrong 1992; Carvalho et al., 1997). In the beginning the formation of watery, non-embryogenic callus was observed after 2 weeks, from which yellowish embryogenic callus developed upon subculturing after 5 weeks of incubation (Fig. 1). In some cases, nodular pale yellow coloured embryoid like structures arose directly from mature grains that formed pseudoshoots. In a very few cases, compact yellow coloured callus developed direcly from the grain. Maintenance of embryogenic callus was done by subculturing after every 45 weeks with reduced levels of auxins.

The level of auxin was investigated for induction of somatic embryogenesis. In 
general, the higher levels of 2,4-D and picloram used for callus induction prevented embryogenesis. However, when the obtained calli were transferred to medium supplemented with reduced (half levels) of auxins, exhibited frequent embryogenesis (Fig. 1). For induction of somatic embryogenesis it was established that media composition, i.e., $\mathrm{MS}+\mathrm{Pic}\left(5.0 \mathrm{mgL}^{-1}\right)+$ BAP $\left(3.0 \mathrm{mgL}^{-1}\right)$ was better for induction of somatic embryogenesis for all inbreds.

After callus establishment, induced embryogenic calli were cultured on regeneration medium to see the effect of different media compositions on per cent shoot regeneration. Ten different media compositions were given in Table 1. Mature somatic embryos turned green after 4-5 days under continuous illumination (Fig. 1) and shoots were formed within 1 week (Fig. 1). Among the ten media compositions thus tried for regeneration, the maximum $(28.3 \%)$ shoot regeneration (Fig. 1) was observed on medium with Proline $\left(3.0 \mathrm{mgL}^{-1}\right)+$ BAP (3.0 $\left.\mathrm{mgL}^{-1}\right)+$ Kinetin $\left(0.5 \mathrm{mgL}^{-1}\right)+$ Gelrite (0.2\%). Jain et al., (2005) established protocol for shoot multiplication of shoot tips on MS medium containing IAA, BAP and Kinetin. They reported that the maximum shoot multiplication occurred on MS medium containing $0.5 \mathrm{mgL}^{-1}$ each of IAA, BAP and Kinetin. Similarly, Mittal (2005) established protocol for shoot multiplication from embryogenic calli on MS medium containing different combinations of growth regulators and reported $\mathrm{MS}+\mathrm{BAP}\left(0.5 \mathrm{mgL}^{-1}\right)+$ Kinetin $\left(0.5 \mathrm{mgL}^{-1}\right)+$ Inositol $\left(200 \mathrm{mgL}^{-1}\right)+$ Sucrose $(3 \%)$ as the best medium.

Huang and Wei (2004) observed that the somatic embryos obtained from mature seeds as explants were transferred to MS medium containing BAP $\left(3.0 \mathrm{mgl}^{-1}\right)$ for germination which was found to be the best medium for germination, while MS supplemented with
BAP $\left(1.0 \mathrm{mgl}^{-1}\right)$, IAA $\left(0.1 \mathrm{mgl}^{-1}\right)$, hydrolytic casein $\left(500 \mathrm{mgl}^{-1}\right)$ and sucrose $\left(30 \mathrm{gl}^{-1}\right)$ by sun et al., (2004) were reported to be the best medium for regeneration from embryogenic callus of maize. Organogenesis was observed with the appearance of green leaves and white compact structures which resembled the scutellar tissue of in vivo embryos of maize Green and Phillips (1975).

It was interesting that when the concentration of BAP was increased from $2 \mathrm{mgL}^{-1}$ to 4 $\mathrm{mgL}^{-1}$, there was increase in per cent regeneration in all the genotypes. There was drastic decline in per cent regeneration when 2,4-D $\left(0.25 \mathrm{mgL}^{-1}\right)$ alone or in combination with NAA (1.0 $\left.\mathrm{mgL}^{-1}\right)$ was used. Efficient shoot regeneration from mature embryos was obtained on regeneration medium containing 6- BAP $(2.22 \mu \mathrm{M})$ in combinations with 4.64 $\mu \mathrm{M}$ Kinetin by Zhao et al., (2008). This is in contrast to the findings of Wang et al., 1987 who obtained plant regeneration from mature embryos by using different concentrations of 2,4-D. Oduor et al., (2006) reported a reduced regeneration frequency for tropical maize lines as compared to temperate lines from immature embryos. This poor response may be due to the recalcitrance nature of tropical maize genotypes to tissue culture conditions developed using temperate lines. However, considering the year round availability and abundance, the use of mature embryos as an alternative explant source can be useful in maize tissue culture and transformation studies. Furthermore, despite few reports about the recalcitrance of tropical maize lines and mature embryos for tissue culture work (Bohorova et al., 1995; Hodges et al., 1986), successful regeneration of temperate maize lines and other cereal food crops from mature embryos has been reported by several research workers (Green and Phillips, 1975; Wang, 1987; Rueb et al., 1994; Ozgen et al., 1998; Akula et al., 1999; Ward and Jordan, 2001). Green et al., (1975) first reported that 
mature embryos of maize could be used to induce callus but no plantlets were regenerated. Huang and Wei (2004) reported regeneration of temperate maize lines from mature embryos at a frequency ranging from 19.85 to $32.4 \%$. Most recently Al-Abed et al., (2006) reported more efficient regeneration system for two hybrid and two inbred temperate maize lines using split mature seeds as an explant. The somatic embryos obtained from immature embryos and mature seeds as explants were transferred to MS medium containing BAP $\left(3.0 \mathrm{~m} \mathrm{gL}^{-1}\right)$ for germination which was found to be the best medium for germination. Regeneration of shoots from mass of somatic embryos on MS medium supplemented with BAP $\left(0.5 \mathrm{mgL}^{-1}\right)$ by Huang and Wei (2004), while MS supplemented with BAP $\left(1.0 \mathrm{mgL}^{-1}\right)$, IAA $\left(0.1 \mathrm{mgL}^{-1}\right)$, hydrolytic casein $\left(500 \mathrm{mgL}^{-1}\right)$ and sucrose $\left(30 \mathrm{gL}^{-1}\right)$ by Sun et al., (2004) were reported to be the best medium for regeneration from embryogenic callus of maize. Organogenesis was observed with the appearance of green leaves and white compact structures which resembled the scutellar tissue of in vivo embryos of maize Green and Phillips (1975). The most probable reason for this could be the role of genetic background in the formation of the Type II callus (Armstrong and Green 1985). Abebe et al., (2008) used mature zygotic embryos using split seed technique. The maximum average callus induction recorded using LS basal salts and B5 vitamins supplemented with $3 \mathrm{mgL}^{-1}$ 2,4-D alone was $90 \%$ and $52.5 \%$ when same level of 2,4-D was combined with Kinetin. Al-Abed et al., (2006) induced shoots from split-seed and observed that maximum number of shoots equaled 30 per explant when BAP and Kinetin were combined at 17.6 and $9.2 \mu \mathrm{M}$, respectively. It has also been observed that media MS+ Proline (3.0g) + BAP (3.0) + Kn (0.5) + Gelrite $(0.2 \%) \mathrm{mgL}^{-1}$ proved to be the best combination for shoot induction for both LM6 and Lm13 inbreds. Genotype plays a chief role in tissue culture response across crop plants. Bohorova et al., (1995) reported genotype dependent regeneration response among tropical and sub-tropical maize lines. Genotype dependent regeneration response has also been demonstrated by various authors (Wenbin et al., 2002; AguadoSantacruz et al., 2007). Genotypic differences in terms of regeneration response might be related to disparity in endogenouse hormone levels (Norstong, 1970; Bhaskaran and Smith, 1990). This work would act as a starting point for developing an efficient protocol for embryogenic callus production in maize inbred lines and their further use in biotechnological research for development of transgenic plants.

\section{Abbreviations}

MS: Murashige and Skoog medium, BAP: 6Benzylamino purine, Pic: 4- Amino-3,6,6trichloropicolinic acid (picloram), 2, 4-D: 2, 4-Dichlorophenoxyacetic acid.

\section{References}

Abebe, D.Z., Teffera W. and Machuka J. 2008. Regeneration of tropical maize lines (Zea mays L.) from mature zygotic embryo through callus initiation. African Journal of Biotechnology 7: 2181-2186.

Aguado-Santacruz, G. A., E. García-Moya, J.L. Aguilar-Acuña, B. Moreno-Gómez, E. Solís-Moya, E. R. Preciado-Ortiz, J.F. Jiménez-Bremont and Q. RascónCruz. 2007. In vitro plant regeneration from quality protein maize (QPM) In Vitro Cellular and Developmental Biology Plant: 215-224.

Akula, C., A. Akula and R. Henry. 1999. Improved regeneration efficiency from mature embryos of barley cultivars. Biology Plant. 42:505-513. 
Al-Abed, D., P. Madasamy, R. Talla, S. Goldman and S. Rudrabhatla (2006) Genetic Engineering of Maize with the Arabidopsis DREB1A/CBF3 Gene Using Split-Seed Explants. Crop Science 47: 2390-2402.

Anami, S. E., J. M. Allan., C. Taracha, G. Coussens, M. Karimi, P. Hilson, M. V. Lijsebettens, J. Machuka (2010) Somatic embryogenesis and plant regeneration of tropical maize Genotypes. Plant Cell Tissue Organ Culture 102:285-95.

Armstrong, C.L. and Green C.E. 1985. Establishment and maintenance of friable, embryogenic maize callus and involvement of proline. Planta 164: 207-214.

Armstrong, C.L., J. Romero and T. K. Hodges. 1992 Improved Tissue Culture Response of an Elite Maize Inbred Through Backcross Breeding, and Identification of Chromosomal Regions Important for Regeneration by RFLP Analysis. Theoratical and Applied Genetics 84:755-762.

Bhaskaran, S. and R.H. Smith. 1990. Regeneration in cereal tissue culture: A review. Crop Sci 30: 1328-1336.

Bohorova, N. E., B. Luna, R. M. Brito, L. D. Huerta, D. A. Hoisington. 1995. Regeneration potential of tropical, subtropical, midaltitude and highland maize inbreds. Maydica 40: 275-281.

Carvalho, C.H., N. Bohorova, P.N. Bordallo, L.L. Abreu, F.H. Valicente, W. Bressan and E. Paiva. 1997. Type II callus production and plant regeneration in tropical maize genotypes. Plant Cell Reports 17: 73-76

Cheema, H.S. and B. Singh. 1990. A user's manual to CPCS-1. A Computer Programme Package for the Analysis of Commonly used Experimental Designs, PAU, Ludhiana.
Eisinger, W.R. and D.J. Morré. 1971. Growth-regulating properties of picloram, 4-amino-3,5,6trichloropicolinic acid. Canadian Journal of Botany 49: 889-897.

Frame, B.R., H. Shou, R.K. Chikwamba, Z. Zhang, C. Xiang, T.M. Fonger, S.E.K Pegg, B. Li, D.S. Nettleton, D. Pei, K. Wang. 2002. Agrobacterium tumefaciens-mediated transformation of maize embryos using a standard binary vector system. Plant Physiology 129:13-22.

Green, C.E. and R.L. Phillips 1975. Plant regeneration from tissue cultures of maize. Crop Science 15: 417-420.

Green, C.E., R.L. Phillips, R.A. Kleese. 1974. Tissue culture of maize (Zea mays L.): initiation, maintenance, and organic growth factors. Crop Science 14: 54-58.

Hodges, T. K., K. K. Kamo, C. W. Imbrie and M. R. Beckwar. 1986. Genotype specificity of somatic embryogenesis and regeneration in maize. Biotechnology 4: 219-229.

Huang, X.Q. and Z.M. Wei. 2004. Highfrequency plant regeneration through callus initiation from mature embryos of maize (Zea Mays L.). Plant Cell Reports 22: 293-800.

Murashige, T., Skoog F. 1962. A revised medium for rapid growth and bioassays with tobacco tissue cultures. Plant Physiology 115: 473-497.

Norstong, K. 1970. Induction of embryo like structures by kinetin in cultured barley embryos. Developmental Biology 23:665-670.

Oduor, R.O., S. Ndung'u, E.N. Njagi and J. Machuka. 2006. In vitro regeneration of dryland Kenyan maize genotypes through somatic embryogenesis. International Journal of Botany 2: 146151.

Ozgen, M., M. Turet, S. Altmok and C. Sancak. 1998. Efficient callus culture 
induction and plant regeneration from embryo culture of winter maize (Triticum aestivum L.) genotypes. Plant Cell Reports 18: 331-335.

Pingali, P. L., S. Pandey. 2001. World Maize Needs Meeting: Technological Opportunities and Priorities for the Public Sector. CIMMYT, Mexico. pp. $1-3$.

Prioli, L.M., W.J. Silva. 1989. Somatic embryogenesis and plant regeneration capacity in tropical maize inbreds. Brazilian Journal of Genetics 12:553566.

Rueb, S., M. Leneman, R. Schilperoort, L. Hensgens. 1994. Efficient plant regeneration through somatc embryogenesis from callus induced on mature rice embryos (Oryza sativa L.). Plant Cell Tissue Organ Culture. 36:259-264.

Schnable, P.S. and K. Wang. 2009. Production of transgenic maize from bombarded type II callus: Effect of gold particle size and callus morphology on transformation efficiency. In vitro cellular and developmental biology 36: 21-29.

Strable, J. and M.J. Scanlon. (2009) Maize (Zea mays): a model organism for basic and applied research in plant biology. Cold Spring Harb Protoc 10: pdb emo132, doi:10.1101/pdb.emo132 (2009).

Sun, Y., J. X. Wang, H. Jingjing and C. Guimie (2004) Factors affecting the frequencies of callus induction and plant regeneration in maize immature embryo culture. Acta Agronomica Sinica 30: 398-402.

Wang, A.S. 1987. Callus induction and plant regeneration from maize mature embryos. Plant Cell Reports 6: 360362.

Ward, K. and M. Jordan. 2001. Callus formation and plant regeneration from immature and mature maize embryos of rye (Secale ereale L.). In Vitro Cellular Developmental Biology- Plant 37:361368.

Wenbin, L.I., P. Masilamany, K.J. P. Kasha, K. Pauls. 2002. Developmental, tissue culture and genotypic factors affecting plant regeneration from shoot apical meristems of germinated Zea mays L. seedlings. In Vitro Cellular Developmental Biology- Plant 38:285292.

Xu, Y., D.J. Skinner, H. Wu, N. PalaciosRojas, J.L. Araus, J. Yan, S. Gao, M.L. Warburton, J.H. Crouch. 2009. Advances in maize genomics and their value for enhancing genetic gains from breeding. International Journal of Plant Genomics: doi:10.1155/2009/957602

Zhao, C. H., L. J. Zhang., C. Ge, Hu K. 2008. Establishment and optimization of the regeneration system of mature embryos of maize (Zea mays L.). Agricultural Sciences in China 7, 1046-1051.

\section{How to cite this article:}

Dhillon, N.K. and Gosal, S.S. 2018. In vitro Regeneration by Somatic Embryos of Maize Inbreds Using Mature Seeds. Int.J.Curr.Microbiol.App.Sci. 7(11): 725-733. doi: https://doi.org/10.20546/ijcmas.2018.711.087 